\title{
Deskripsi Kecerdasan Visual Spasial Siswa dalam Memecahkan Masalah Bangun Ruang Sisi Datar Ditinjau Berdasarkan Tingkat Kemampuan Awal Geometri pada Siswa Kelas VII SMP
}

\author{
Anisah Syafiqah ${ }^{1, \text { a) }}$, Ruslan ${ }^{1, \text { b) }}$, dan Darwis ${ }^{1, c)}$ \\ ${ }^{1}$ Jurusan Matematika, Fakultas MIPA, Universitas Negeri Makassar \\ a)anisah.syafiqah243@gmail.com \\ b) ruslan_math_unm@yahoo.com \\ c)darwismath.2018@gmail.com
}

\begin{abstract}
Abstrak. Penelitian ini bertujuan untuk mengetahui gambaran umum kecerdasan visual spasial siswa kelas VII SMP dalam memecahkan masalah bangun ruang sisi datar berdasarkan tingkat kemampuan awal geometri. Penelitian ini menggunakan Teori Hass yang menggolongkan karakteristik kecerdasan visual spasial atas pengimajinasian, pengkonsepan, pemecahan masalah, dan pencarian pola. Jenis penelitian ini adalah penelitian deskriptif dengan pendekatan kualitatif. Subjek penelitian sebanyak 3 siswa, yaitu 1 siswa dengan kemampuan awal geometri tinggi, 1 siswa dengan kemampuan awal geometri sedang dan 1 siswa dengan kemampuan awal geometri rendah. Instrumen penelitian yang digunakan terdiri atas soal tes kemampuan awal geometri, soal tes kecerdasan visual spasial materi bangun ruang sisi datar, dan pedoman wawancara. Hasil penelitian menunjukkan bahwa : (1) Karakteristik yang paling dominan muncul pada siswa adalah karakteristik pencarian pola serta pengimajinasian sedangkan karakteristik yang paling tidak dominan muncul adalah karakteristik pemecahan masalah. (2) Subjek berkemampuan awal geometri tinggi 3 karakteristik kecerdasan visual spasial yakni pengimajinasian, pengkonsepan dan pencarian pola. (3) Subjek berkemampuan awal geometri sedang mampu memenuhi 2 karakteristik kecerdasan visual spasia yakni pengimajinasian dan pencarian pola. (4) Subjek berkemampuan awal geometri rendah tidak mampu memenuhi semua karakteristik kecerdasan visual spasial.
\end{abstract}

Kata kunci: Kecerdasan, Kecerdasan Visual Spasial, Kemampuan Awal Geometri, Bangun Ruang Sisi Datar, Teori Hass

\begin{abstract}
The aim of this research is to determine the general description of spatial visual intelligence of students from grade VII of SMP in solving solid figure flat side problems based on the initial ability level of geometry. This research used Hass Theory which classifies the characteristics of spatial visual intelligence based of imagining, conceptualizing, problem solving, and problem seeking. The type of this research is descriptive research with qualitative approach. The research subjects were 3 students. The first subject has high initial ability in geometry, the second subject has moderate initial ability, and the third subject has low initial ability. The research instrument used consists of the initial ability of geometry test questions, spatial visual intelligence of solid figure flat side test questions, and interview guidelines. The research result showed that: (1) The most dominant characteristic that appears in students was the characteristic of problem seeking and imagining, while the least dominant characteristic was problem solving. (2) Subjects who had high initial ability of geometry was able to fulfill 3 spatial visual intelligence characteristics, those were imagining, conceptualizing, and problem seeking. (3) Subjects who had moderate initial ability of geometry was able to fulfill 2 spatial visual intelligence characteristics, those were imagining and problem seeking. (4) Subjects who had low initial ability of geometry was not able to fulfill all the characteristics of spatial visual intelligence.
\end{abstract}

Keywords: Intelligence, Visual-Spatial Intelligence, Initial ability of Geometry, Solid Figure Flat Side, Hass Teory 


\section{PENDAHULUAN}

Kecerdasan merupakan kemampuan untuk memecahkan atau menciptakan sesuatu yang bernilai bagi budaya tertentu (Gardner, 1983). Pendapat tersebut menunjukkan bahwa ketika seseorang memiliki kemampuan untuk memecahkan suatu masalah maka seseorang tersebut dikatakan memiliki kecerdasan. Kecerdasan yang dimiliki setiap orang setidaknya terdiri atas delapan jenis walaupun hanya beberapa kecerdasan saja yang dominan (Gardner, 1983). Dimana salah satu kecerdasan tersebut adalah kecerdasan visual spasial.

Kecerdasan visual spasial merupakan kemampuan untuk berpikir tiga dimensi. Seseorang yang memiliki kecerdasan visual spasial mempunyai kapasitas untuk mengelola gambar, bentuk, dan ruang tiga dimensi (Gardner, 1983). Kemampuan pengelolaan tersebut dilakukan melalui aktivitas mengenali bentuk, warna, ruang, dan menciptakan gambar secara mental maupun realistis. Melalui aktivitas tersebut seseorang mampu menghasilkan imajinasi, representasi grafis, dan mampu mencipta ulang dunia visual. Mencipta ulang dunia visual disebut dengan visualisasi. Visualisasi dalam matematika tidak hanya berupa analitis matematis melainkan mencakup aspek lain seperti geometri atau yang berhubungan dengan aspek keruangan (Pitriani, 2014).

Geometri merupakan kajian dalam matematika yang mempelajari titik, garis, bidang, bangun ruang, sifat-sifat, ukuran serta hubungannya satu sama lain (Sari, Rizal \& Hajar, 2017). Geometri merupakan salah satu kajian yang bersifat abstrak. Sehingga dalam mempelajarinya, siswa dituntut untuk memiliki kecerdasan visual spasial. Hal tersebut disebabkan karena kecerdasan visual spasial meliputi kemampuan merepresentasikan ide secara visual atau spasial. Dimana kemampuan tersebut merupakan kecerdasan pendukung dalam mempelajari geometri (Fadilah \& Afifah, 2014).

Kecerdasan visual spasial memegang peranan penting dalam keberhasilan pembelajaran geometri (Pitriani, 2014). Hal tersebut disebabkan karena tanpa menggunakan kemampuan visual maka siswa akan rawan mengalami miskonsepsi. Siswa sering kali memahami rumus secara terpisah dengan objek geometrinya. Sehingga, dapat dikatakan bahwa kecerdasan visual spasial erat kaitannya dengan kemampuan awal matematika, khususnya geometri. Berkesinambungan dengan penelitian yang dilakukan oleh Margaretha, Susanto \& Fatahillah (2015) yang menyatakan bahwa terdapat hubungan positif antara kecerdasan visual spasial dengan tingkat kemampuan geometri.

Terdapat beberapa penelitian yang berkaitan dengan kecerdasan visual spasial (Ningsih \& Budiarto, 2014; Sari, Rizal \& Hadjar, 2017; Ningrum \& Hermanto, 2018; Farisdianto \& Budiarto, 2014; Margaretha, Susanto \& Fatahillah, 2015; Librianti, Sunardi \& Sugiarti, 2015; Febriana, 2015; Achdiyat \& Utomo, 2017). Ningsih \& Budiarto (2014) meneliti tentang kecerdasan visual spasial siswa SMP dalam mengkontruksi rumus phytagoras dengan pembelajaran berbasis geometri. Adapun Ningrum \& Hermanto (2018) meneliti tentang kemampuan spasial siswa SMP dalam menyelesaikan masalah geometri ditinjau dari perbedaan gaya kognitif.

Penelitian ini berfokus pada kecerdasan visual spasial siswa yang mempunyai kemampuan geometri tinggi, sedang dan rendah dalam memecahkan masalah berdasarkan Teori Hass. Subjek pada penelitian ini yaitu siswa kelas VII SMP. Penelitian ini bertujuan untuk mengetahui bagaimana kecerdasan visual spasial siswa dalam memecahkan masalah bangun ruang sisi datar. Adapun bangun ruang yang termasuk bangun ruang sisi datar yaitu kubus, balok, prisma dan limas.

\section{KAJIAN PUSTAKA}

\section{Kecerdasan Visual Spasial}

Kecerdasan visual spasial adalah kemampuan persepsi dan kognitif yang menjadikan seseorang mampu untuk melihat hubungan ruang (Carter, 2010). Sedangkan menurut Febriana (2015) 
menyatakan bahwa kecerdasan visual spasial adalah kemampuan yang berhubungan dengan kemampuan mempresentasi, mentransformasi dan memanggil kembali informasi simbolis. Armstrong (2013) pula menyatakan bahwa kecerdasan visual spasial merupakan kemampuan menangkap ruang secara tepat. Serta kecerdasan visual spasial menjadikan seseorang mampu untuk memvisualisasikan gambar, mengenal bentuk dan benda, melakukan perubahan suatu benda dalam pikirannya dan kemudian mewujudkannya dalam visual yang nyata, mengungkapkan data dalam bentuk grafik, dan memiliki kepekaan terhadap keseimbangan, warna, garis, bentuk dan ruang. Sehingga dapat disimpulkan bahwa kecerdasan visual spasial adalah kemampuan dalam melihat hubungan ruang, mempresentasikan, mentransformasikan, dan memanggil kembali informasi simbolik serta kemampuan untuk menggambarkan sesuatu yang ada dalam pikiran kemudian mewujudkannya dalam bentuk nyata.

Penelitian mengenai kecerdasan visual spasial telah dilakukan oleh Ningsih \& Budiarto (2014). Ningsih \& Budiarto (2014) membahas mengenai kecerdasan visual spasial siswa SMP dalam mengkontruksi rumus phytagoras dengan pembelajaran berbasis origami di kelas VIII. Hasil yang diperoleh yaitu subjek dengan kemampuan matematika tinggi dapat menggunakan semua karakteristik, subjek dengan kemampuan matematika sedang dan rendah dapat menggunakan beberapa karakteristik dari kecerdasan visual spasial.

Adapun penelitian yang dilakukan Ningrum \& Hermanto (2018) membahas mengenai kemampuan spasial siswa SMP dalam menyelesaikan masalah geometri ditinjau dari perbedaan gaya kognitif. Hasil yang diperoleh yaitu pada tahap memahami masalah seluruh subjek menggunakan kemampuan spasial dengan pengimajinasian dan pengkonsepan. Dalam merencanakan penyelesaian masalah, subjek FI (Field Independent) menggunakan pengimajinasian, pengkonsepan dan pencarian pola sedangkan subjek FD (Field Dependent) hanya pengimajinasian dan pengkonsepan. Dalam melaksanakan rencana penyelesaian masalah, seluruh subjek menggunakan pengimajinasian, pengkonsepan dan pencarian pola. Dalam memeriksa kembali, subjek FD menggunakan pengkonsepan tetapi tidak melalui pengimajinasian dan pencarian pola sedangkan subjek FI dengan pengimajinasian dan pengkonsepan tetapi tidak melalui pencarian pola.

Karakteristik kecerdasan visual spasial menurut teori Hass yang dikemukakan oleh Ningsih dan Budiarto (2014) untuk mendeskripsikan karakteristik kecerdasan visual spasial siswa, yaitu :

1. Pengimajinasian (Imagination)

Siswa dengan kecerdasan visual spasial lebih banyak belajar dengan melihat daripada mendengarkan. Pada saat presentasi siswa lebih aktif dan tertarik membuat gambar visual dalam menyajikan informasi, siswa lebih mudah dalam memahami permasalahan perspektif serta mempelajari konsep berdasarkan dari apa yang dilihat.

2. Pengkonsepan (Conceptualization)

Siswa yang memiliki kecerdasan visual spasial adalah siswa holistik yang memegang konsep lebih baik daripada kenyataan-kenyataan individu. Siswa menyatukan dan membangun kerangka kerja konseptual untuk menunjukkan hubungan antara topik tertentu dan seluruh objek.

3. Pemecahan masalah (Problem Solving)

Siswa yang spasial adalah pemikir yang berbeda, yang lebih memilih jalur solusi yang tidak biasa dan beberapa strategi untuk pemecahan masalah. Mereka menikmati bermain-main dengan masalah dan terkadang menemukan lima atau lebih strategi dalam pemecahan masalah. Proses ini lebih menarik dibandingkan dengan jawaban yang biasa dilakukan oleh siswa pada umumnya.

4. Pencarian pola (Problem Seeking)

Siswa dengan kemampuan spasial tinggi, tidak hanya unggul dalam menemukan pola pada angka-angka tetapi juga mampu menemukan pola secara berurutan serta menghubungkan dengan prinsip matematika. Adapun beberapa indikator yang dapat digunakan untuk mengenali karakteristik pencarian pola. 
TABEL 1. Indikator Kecerdasan Visual Spasial Menurut Teori Hass

\begin{tabular}{|c|c|c|c|}
\hline No & Karakteristik & & Indikator \\
\hline 1. & Pengimajinasian & a) & $\begin{array}{l}\text { Siswa mampu menggunakan bantuan } \\
\text { gambar dalam menyelesaikan } \\
\text { permasalahan }\end{array}$ \\
\hline & & b) & $\begin{array}{l}\text { Siswa mampu menuangkan ide atau hasil } \\
\text { pemikirannya dalam bentuk gambar } \\
\text { untuk menyelesaikan suatu permasalahan }\end{array}$ \\
\hline 2. & Pengkonsepan & a) & $\begin{array}{lcc}\text { Siswa mampu } & \text { menyebutkan } & \text { konsep- } \\
\text { konsep yang } & \text { berkaitan } & \text { dengan } \\
\text { permasalahan } & & \end{array}$ \\
\hline & & b) & $\begin{array}{l}\text { Siswa mampu menggunakan konsep- } \\
\text { konsep tersebut untuk menyelesaikan } \\
\text { permasalahan }\end{array}$ \\
\hline 3. & Penyelesaian Masalah & & $\begin{array}{l}\text { Siswa mampu menyelesaikan } \\
\text { permasalahan dengan benar }\end{array}$ \\
\hline 4. & Pencarian Pola & & $\begin{array}{l}\text { Siswa mampu menemukan pola dalam } \\
\text { menyelesaikan permasalahan }\end{array}$ \\
\hline
\end{tabular}

Tabel 1 merupakan indikator kecerdasan visual spasial yang dicantumkan oleh Librianti, Sunardi dan Sugiarti (2015). Indikator tersebut pada penelitian ini digunakan untuk mendeskripsikan kecerdasan visual spasial yang dimiliki oleh siswa.

\section{METODE PENELITIAN}

Penelitian ini adalah penelitian kualitatif dengan menggunakan pendekatan deskriptif. Subjek penelitian ini adalah 3 orang siswa kelas VII SMP yang masing-masing dengan satu orang siswa berkemampuan awal geometri tinggi, satu orang berkemampuan awal geometri sedang dan satu orang siswa berkemampuan awal geometri rendah.

Instrumen yang digunakan yaitu tes soal kemampuan awal geometri berbentuk pilihan ganda, tes soal kecerdasan visual spasial berbentuk uraian, dan pedoman wawancara yang masingmasing telah divalidasi oleh dua orang ahli. Teknik pengumpulan data dalam penelitian ini yaitu menggunakan tes untuk mengkategorikan kemampuan awal geometri dan untuk mengetahui kecerdasan visual spasial yang dimiliki siswa, serta wawancara untuk memperoleh informasi lebih lanjut mengenai jawaban subjek pada tes kecerdasan visual spasial serta menggali informasi baru yang mungkin tidak diperoleh pada saat tes.

Pengambilan data dalam penelitian ini dimulai dengan memberikan tes soal kemampuan awal geometri kepada 61 orang siswa guna menetapkan subjek penelitian. Penetapan subjek penelitian ini berdasarkan hasil tes kemampuan awal geometri yang diberikan tersebut. Berikut kategori penilaian kemampuan awal geometri siswa berdasarkan skor yang diperoleh sebagai berikut (Mas'um, 2013).

1. Kategori siswa dengan kemampuan awal tinggi $(80 \leq x \leq 100)$

2. Kategori siswa dengan kemampuan awal sedang $(60 \leq x<80)$, dan

3. Kategori siswa dengan kemampuan awal rendah $(x<60)$.

Adapun rincian masing-masing subjek yang terpilih disajikan dalam Tabel 2.

TABEL 2. Penetapan Subjek Penelitian

\begin{tabular}{cccc}
\hline No & Kemampuan Awal & Skor Tes & Kode Siswa \\
\hline 1. & Tinggi & 90 & S1a \\
2. & Sedang & 60 & S2a \\
3. & Rendah & 40 & S3a \\
\hline
\end{tabular}


Tabel 2 merupakan hasil dari tes kemampuan awal geometri. Tabel tersebut menunjukkan tiga subjek yang terpilih pada masing-masing kategori kemampuan awal geometri.

Setelah dilakukan pemilihan subjek, selanjutnya subjek yang telah terpilih, kemudian diberikan tes kecerdasan visual spasial dan diwawancarai. Kemudian menganalisis kecerdasan visual spasial berdasarkan hasil tes kecerdasan visual spasial dan hasil wawancara tiap subjek. Data dari hasil tes dan wawancara tersebut kemudian dideskripsikan. Deskripsi dari wawancara tersebut akan menggambarkan kecerdasan visual spasial untuk setiap kemampuan awal geometri. Yang terakhir adalah penyajian data, data hasil tes dan wawancara tersebut disajikan dalam bentuk naratif.

\section{HASIL DAN PEMBAHASAN}

\section{Subjek Berkemampuan Awal Geometri Tinggi (S1a)}

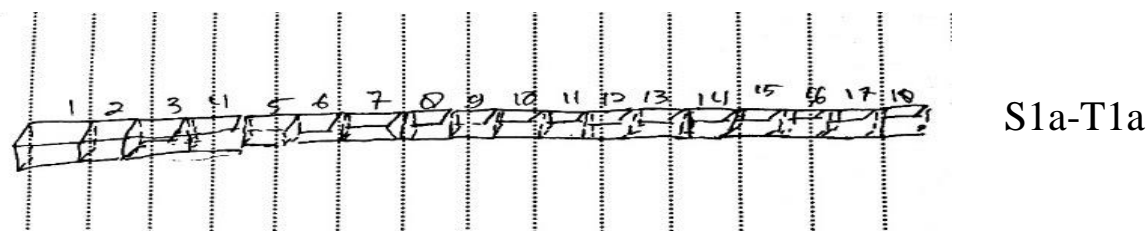

GAMBAR 1. Jawaban subjek S1a pada nomor 1

Pada Gambar 1 dapat dilihat bahwa subjek S1a menggambarkan sebuah balok yang terdiri dari 18 buah kubus satuan di mana jawaban yang subjek tuliskan tersebut sudah tepat (S1a-T1a). Oleh karena itu, subjek S1a telah menuangkan idenya berupa gambar balok seperti yang diinstruksikan oleh soal. Hal ini diperkuat pada cuplikan wawancara subjek S1a pada Transkrip 1 .

\section{TRANSKRIP 1}

P2-07 Oh begitu ya. Dari yang adek gambar ini, apa buktinya jika itu adalah sebuah balok?

S1a-W207 Mempunyai 6 sisi kak

P2-08 Kubus juga punya 6 sisi, terus apa bedanya?

S1a-W208 Sisinya balok itu kak tidak sama, jadi yang saya gambar ini panjangnya 18, terus lebarnya 1 terus tingginya 1 kak

Pada Transkrip 1, subjek S1a menjelaskan bangun yang ia gambarkan dikatakan sebuah balok karena memiliki 6 sisi (S1a-W207). Lanjut subjek, sisi balok itu tidak selalu sama seperti balok dan subjek S1a juga menyebutkan ukuran dari balok yang ia gambarkan (S1a-W208).

Subjek S1a telah menuangkan idenya dalam bentuk gambar untuk menyelesaikan permasalahan yang diberikan. Subjek juga mampu memberikan penjelasan mengenai bangun yang ia gambarkan. Dari hasil tes pada Gambar 1 dan hasil wawancara pada Transkrip 1, subjek S1a dapat mampu memenuhi indikator menuangkan ide atau hasil pemikirannya dalam bentuk gambar untuk menyelesaikan permasalahan yang diberikan dengan baik yang mewakili karakteristik pengimajinasian.

Pada Gambar 2 dapat dilihat bahwa subjek S1a menuliskan beberapa operasi perhitungan. Kemudian subjek S1a tampak menggunakan konsep-konsep yang ia ketahui untuk menyelesaikan permasalahan di mana subjek menyelesaikan semua operasi perhitungan yang ia tuliskan dengan tepat (S1a-T2a). Namun, subjek tidak menulis rumus apa yang ia gunakan sehingga sulit dipahami Terlepas dari hal tersebut, subjek S1a telah menggunakan konsepkonsep yang ia ketahui untuk menyelesaikan permasalahan yang diberikan dengan tepat. Hal ini diperkuat pada cuplikan wawancara subjek S1 a pada Transkrip 2. 


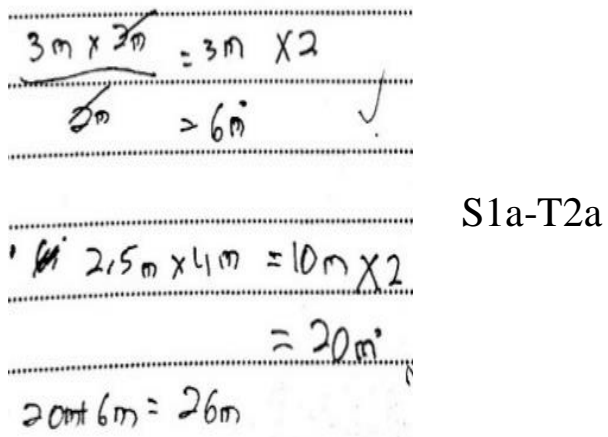

GAMBAR 2. Jawaban subjek S1a soal nomor 2

\section{TRANSKRIP 2}

\begin{tabular}{|c|c|}
\hline P4-04 & $\begin{array}{l}\text { Oiye dek. Setelah membaca soal nomor } 2 \text { ini, apa yang pertama } \\
\text { kali adek lakukan untuk menyelesaikan soalnya? }\end{array}$ \\
\hline S1a-W404 & Mencari luas segitiga kak \\
\hline P4-05 & Setelah itu? \\
\hline S1a-W405 & Dikalikan dua itu luasnya kak \\
\hline P4-07 & Oiye dek. Terus bagaimana lagi? \\
\hline S1a-W407 & Mencari sisi miringnya kak \\
\hline S1a-W408 & $\begin{array}{l}\text { Supaya bisa dicari luasnya persegi panjang kak, kan tidak } \\
\text { diketahui di soal makanya harus dicari }\end{array}$ \\
\hline S1a-W409 & $\begin{array}{l}\text { Setelah saya cakar kak saya dapat sisi miringnya itu 2.5. Nah } \\
\text { setelah itu saya kalikan dengan } 4 \text { kak. }\end{array}$ \\
\hline S1a-W410 & $\begin{array}{l}\text { Karena rumusnya luas persegi kak kan panjang dikali lebar, } \\
\text { makanya } 2.5 \text { dikalikan } 4 \text { hasilnya } 10 \text { kak. }\end{array}$ \\
\hline S1a-W411 & $\begin{array}{l}\text { Kan didapatmi kak luas persegi panjangnya, jadi dikalikan } 2 \text { juga } \\
\text { karena ada } 2 \text { persegi panjang. Terus saya jumlahkan kak luas } 2 \\
\text { segitiga tadi dengan } 2 \text { luas persegi panjang kak. }\end{array}$ \\
\hline & Jadi berapa jawabannya dek? \\
\hline 1a-W412 & $26 K a k$ \\
\hline
\end{tabular}

Pada Transkrip 2, subjek S1a menjelaskan langkah-langkah yang ia gunakan untuk menyelesaikan permasalahan. Dalam hal ini ia menggunakan konsep-konsep yang ia ketahui untuk menyelesaikan permasalahan yakni rumus dari luas segitiga (S1a-W404), rumus dari luas persegi panjang (S1a-W410) dan teorema Pythagoras (S1a-W409). Selain itu, subjek meskipun telah memberikan jawaban yang tepat namun jika ditinjau menurut langkah polya, subjek S1a tidak melakukan tahap looking back.

S1a telah menggunakan konsep yang ia ketahui untuk menyelesaikan permasalahan yang diberikan. Sehingga, dari hasil tes pada Gambar 2 dan hasil wawancara pada Transkrip 2, subjek S1a dapat memenuhi indikator menggunakan konsep-konsep yang ia ketahui untuk menyelesaikan permasalahan yang diberikan dengan baik yang mewakili karakteristik pengkonsepan.

Pada Gambar 3 dapat dilihat bahwa subjek S1a menuliskan informasi yang ia peroleh dari soal (S1a-T3a). Namun, subjek S1a tidak menjawab soal dengan benar di mana dalam hal ini tidak menggunakan rumus yang relevan dengan soal diberikan dan juga ia tampak tidak memahami maksud dari soal dengan baik (S1a-T3b). Oleh karena itu, subjek S1 a tidak dapat menyelesaikan permasalahan yang diberikan dengan benar. Hal ini diperkuat pada cuplikan wawancara subjek S1a pada Transkrip 3. 


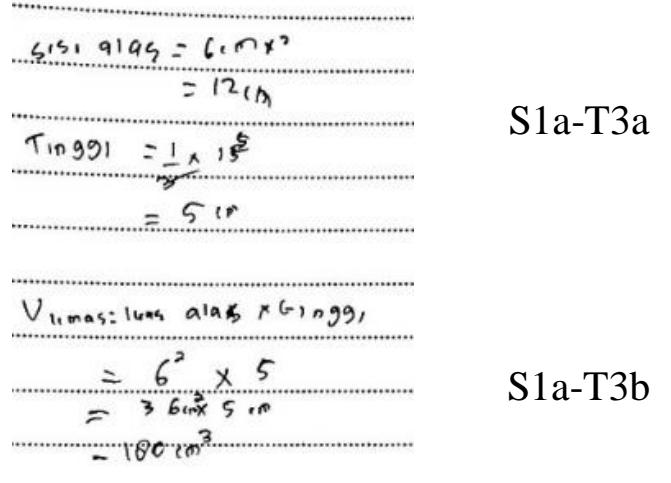

GAMBAR 3. Jawaban subjek S1a soal nomor 3

\section{TRANSKRIP 3}

$\begin{array}{ll}\text { P5-07 } & \text { Bagaimana dengan jawabannya adek? } \\ \text { S1a-W507 } & \text { Salah kak } \\ \text { P5-08 } & \text { Kenapa salah dek? } \\ \text { S1a-W508 } & \begin{array}{l}\text { Pertama kak, ternyata salah pahamka soalnya. Pas saya baca } \\ \text { ulang tadi baru saya pahami. Jadi saya tidak hitung volume } \\ \text { awalnya, cuman volume akhirnya saja. Terus yang kedua kak, salah } \\ \text { rumusku juga. }\end{array} \\ \text { S1a-W511 } & \begin{array}{l}\text { Saya kira prisma kak ini yang mau saya hitung pada saat itu, } \\ \text { makanya saya tidak tulis 1/3nya kak }\end{array}\end{array}$

Pada Transkrip 3, subjek S1a mengaku ia tidak paham dengan maksud soal dan juga subjek S1a mengaku menggunakan rumus yang tidak relevan dengan soal yang diberikan (S1a-W508 \& S1a-W511). Oleh karena itu, subjek S1a tidak menyelesaikan permasalahan yang diberikan dengan benar. Sehingga, dari hasil tes pada Gambar 3 dan hasil wawancara pada Transkrip 3, subjek S1a tidak mampu memenuhi indikator menyelesaikan permasalahan yang diberikan dengan benar yang mewakili karakteristik pemecahan masalah.

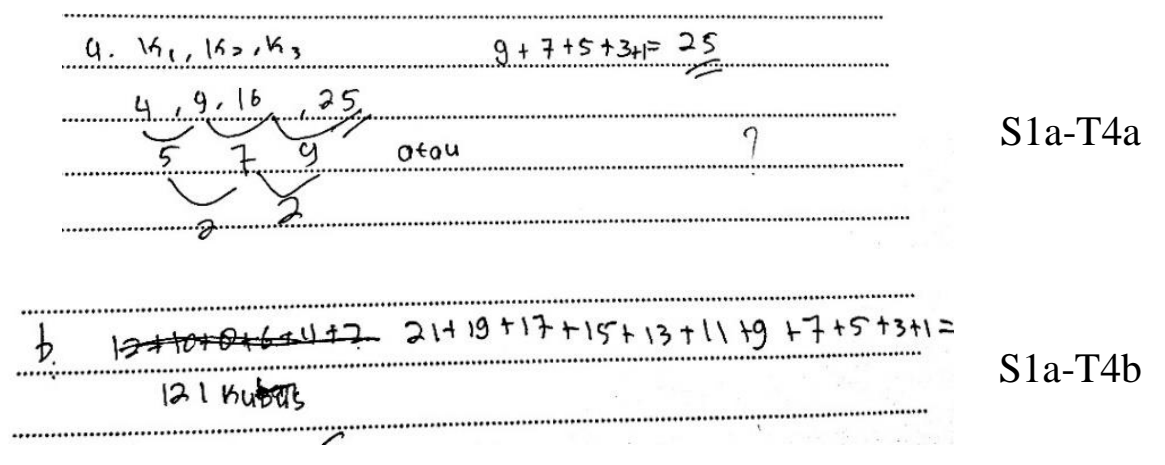

GAMBAR 4. Jawaban subjek S1a soal nomor 4

Pada Gambar 4 dapat dilihat subjek S1a telah menemukan pola lebih dari satu pola lalu subjek S1a gunakan pola tersebut untuk memperoleh jawaban dengan tepat (S1a-T4a). Subjek menggunakan salah satu cara yang ia gunakan di bagian a untuk ia terapkan guna mencari jawaban bagian b di mana jawaban yang dituliskan subjek pun sudah tepat (S1a-T4b). Oleh karena itu, subjek S1a telah menemukan pola dalam menyelesaikan permasalahan yang diberikan. Hal ini diperkuat pada cuplikan wawancara subjek S1 a pada Transkrip 4.

Pada Transkrip 4, subjek S1a ini menemukan pola dalam menyelesaikan permasalahan yang diberikan (S1a-W606). Subjek S1a juga menjelaskan langkah-langkah yang ia gunakan dengan jelas dan rinci (S1a-W607 \& S1a-W609). Sehingga, dari hasil tes pada Gambar 4 dan hasil 
wawancara pada Transkrip 4, subjek S1a dapat mememuhi indikator menemukan pola dalam menyelesaikan permasalahan yang diberikan dengan baik yang mewakili karakteristik pencarian pola.

\section{TRANSKRIP 4}

S1a-W606 Seperti yang saya tulis disini kak. Jadi awalnya itu kak beda-bedaki bedanya.

P6-07 Maksudnya dek?

S1a-W607 Maksudnya kak, kan k1 itu 4 terus k2 itu 9 jadi bedanya 5. Terus bedanya k2 dengan $k 3$ itu kak 7 ternyata. Nah karena itu kak haruski cari lagi bedanya antara 5 sama 7. Makanya saya tulis 2 kak. Jadi kalo diikuti polanya kak nanti didapat hasilnya k4 itu 25.

P6-08 Bagaimana dengan k10? Begitu juga caranya?

S1a-W609 Ternyata kak yang dijumlahkan itu semua bilangan ganjil kak. Jadi untuk $k 4$ itu dijumlahkan semua bilangan ganjil dari 1 sampai 9 kak didapatkan hasilnya 25. Sehingga untuk k10, dijumlahkan semua bilangan ganjil dari 1 sampai 21 kak, diperoleh 121.

\section{Subjek Berkemampuan Awal Geometri Sedang (S2a)}

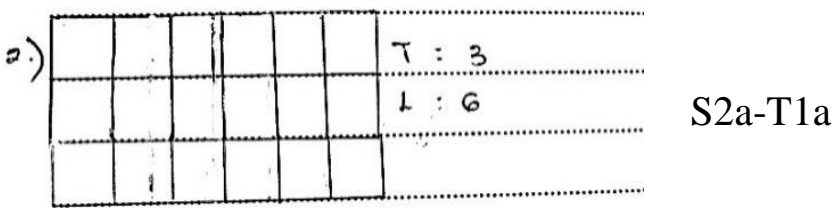

GAMBAR 5. Jawaban subjek S2a soal nomor 1

Pada Gambar 5 dapat dilihat bahwa subjek S2a menuangkan idenya berupa gambar bangun yang lebih tampak seperti bangun datar persegi panjang daripada sebuah balok seperti yang diintruksikan soal. Subjek juga menuliskan " $\mathrm{t}=3$ dan $1=6$ " yang mana merupakan ukuran dari bangun yang ia gambarkan (S2a-T1a). Berikut cuplikan wawancara subjek S1a yang dapat dilihat pada Transkrip 5.

\section{TRANSKRIP 5}

P2-08 Dari jawaban yang adek gambar ini, kenapa gambar tersebut dikatakan sebuah balok?

S2a-W208 Karena panjang, tinggi dan lebarnya itu berbeda kak. Kalau sama kak itu artinya bukan balok tapi kubus

P2-10 Jadi berapa panjang dari balok yang adek gambarkan ini?

S2a-W210 6 kak

P2-12 Lalu tingginya berapa?

S2a-W212 Tingginya kak sudah benar 3.

P2-13 Bagaimana dengan lebarnya dek?

S2a-W213 1 kak. Tapi tidak terlalu kelihatan dari yang saya gambar kak. Jadi kalau dibayangkan 3 dimensi ini kak, ada lebarnya 1 kak

Pada Transkrip 5, subjek S2a menjelaskan bangun yang ia gambarkan adalah sebuah balok dikarenakan memiliki panjang, lebar dan tinggi yang berbeda (S2a-W208). Subjek S2a juga menyebutkan ukuran dari balok yang ia gambarkan walaupun agak berbeda dengan yang ia tuliskan pada lembar jawabannya (S2a-W210, S2a-W212, \& S2a-W213).

S2a, dapat menuangkan idenya berupa gambar dan menjelaskan gambar tersebut sehingga dari hasil tes pada Gambar 5 dan hasil wawancara pada Transkrip 5, subjek S2a dapat memenuhi indikator menuangkan ide atau hasil pemikirannya dalam bentuk gambar untuk menyelesaikan permasalahan yang diberikan yang mewakili karakteristik pengimajinasian. 


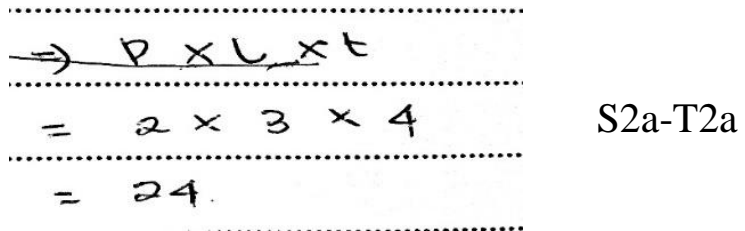

GAMBAR 6. Jawaban subjek S2a soal nomor 2

Pada Gambar 6, Subjek S2a menggunakan konsep yang ia ketahui dalam hal ini ia menuliskan rumus serta operasi perhitungan dan mendapatkan hasil akhir (S2a-T2a). Namun, rumus yang subjek S2a tuliskan yakni rumus dari volume balok yang tidak relevan dengan soal yang diberikan yakni luas daerah permukaan prisma segitiga. Oleh karena itu, subjek S2a tidak dapat menggunakan konsep yang ia ketahui untuk menyelesaikan permasalahan yang diberikan. Hal ini diperkuat pada cuplikan wawancara subjek S2a pada Transkrip 6.

\section{TRANSKRIP 6}

P4-05 Oiye dek. Lalu apa yang pertama kali adek lakukan untuk menyelesaikan soalnya?

S2a-W405 Mengkalikan panjang, lebar dan tingginya kak

P4-06 Kenapa begitu dek?

S2a-W406 Karena tidak saya tahu rumusnya bagaimana kak

Pada Transkrip 6, subjek menjelaskan langkah yang ia gunakan untuk menyelesaikan permasalahan meskipun langkah tersebut kurang tepat (S2a-W405). Subjek S2a juga mengakui bahwa ia tidak mengetahui rumus yang harus ia gunakan (S2a-W406).

Subjek S2a tidak menggunakan konsep yang ia ketahui untuk menyelesaikan permasalahan yang diberikan. Sehingga, dari hasil tes pada Gambar 6 dan hasil wawancara pada Transkrip 6, subjek S2a tidak dapat memenuhi indikator menggunakan konsep-konsep yang ia ketahui untuk menyelesaikan permasalahan yang diberikan dengan tepat yang mewakili karakteristik pengkonsepan.

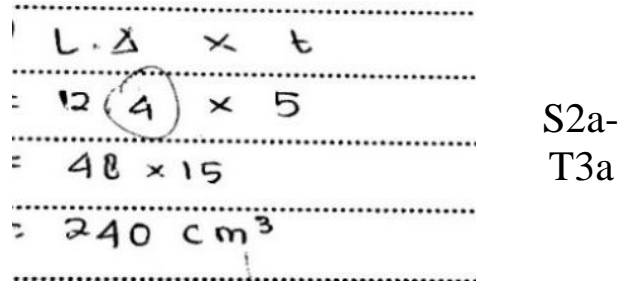

GAMBAR 7. Jawaban subjek S2a soal nomor 3

Pada Gambar 7, subjek S2a tidak menuliskan informasi yang ia peroleh dari soal melainkan ia hanya menuliskan rumus yang ia gunakan untuk menyelesaikan permasalahan yang diberikan diikuti operasi yang ia tuliskan dan memperoleh hasil akhir (S2a-T3a). Namun, rumus yang subjek S2a gunakan kurang tepat, sehingga ia tidak memperoleh jawaban yang tepat. Oleh karena itu, subjek S2a tidak dapat menyelesaikan permasalahan yang diberikan dengan benar. Hal ini diperkuat dengan cuplikan wawancara subjek S2a pada Transkrip 7.

Pada Transkrip 7, subjek S2a menjelaskan langkah-langkah yang ia gunakan dalam menyelesaikan soal nomor 3 sehingga memperoleh hasil akhir. Namun, hasil akhir yang subjek S2a peroleh tidak tepat dikarenakan rumus yang subjek gunakan juga kurang tepat. Selain itu, subjek S2a juga mengaku bahwa ia tidak terlalu paham dengan maksud soal sehingga ia tidak yakin dengan jawaban yang ia tuliskan (S2a-W515). 


\section{TRANSKRIP 7}

P5-10

S2a-W510

P5-11

S2a-W511

P5-12

S2a-W512

P5-15

S2a-W515
Dari jawaban yang adek tuliskan ini, 12 dan 5 yang adek tulis

darimana ya? Kan yang diketahui di soal tidak seperti itu

Oh begini kak, kan panjang awalnya itu 6 terus katanya soal

diperbesar 2 kali makanya jadi 12 kak. Terus tinggi awalnya kan

kak 15 lalu diperkecil 1/3 kali kak makanya hasilnya 5 kak.

Oh iya dek. Terus kenapa adek kalikan 12 itu dengan 4?

Kan segiempat kak, makanya saya kalikan dengan 4

Lalu?

Lalu hasilnya kak saya kalikan dengan tinggi yang sudah diperkecil

kak

Oh begitu ya dek. Jadi adek yakin dengan jawabannya?

Tidak kak. Karena itu tadi saya bilang kak, waktu pengerjaan soal kemarin saya tidak terlalu paham maksud soalnya, jadi sudah pasti salah jawaban saya kak

Subjek S2a tidak dapat menyelesaikan permasalahan yang diberikan dengan tepat. Sehingga, dari hasil tes pada Gambar 7 dan hasil wawancara pada Transkrip 7, subjek S2a tidak dapat memenuhi indikator menyelesaikan permasalahan yang diberikan dengan benar yang mewakili karakteristik pemecahan masalah.

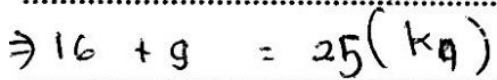

$\Rightarrow 1625+11=36+13 \alpha=49+15=64+17: 81+19=100+21: 121$
S2a-T4a

$\mathrm{S} 2 \mathrm{a}-\mathrm{T} 4 \mathrm{~b}$

GAMBAR 8. Jawaban subjek S2a soal nomor 4

Pada Gambar 8, subjek S2a menuliskan pola yang ia peroleh untuk menyelesaikan permasalahan yang diberikan dan memperoleh jawaban yang tepat untuk soal nomor 4 bagian a (S2a-T4). Menggunakan pola dan langkah yang sama, subjek S2a juga memperoleh jawaban yang tepat untuk bagian b (S2a-T4b). Oleh karena itu, subjek S2a telah menemukan pola dalam menyelesaikan permasalahn yang diberikan. Hal ini diperkuat dengan cuplikan wawancara subjek S2a pada Transkrip 8.

\section{TRANSKRIP 8}

P6-04 Oiye dek. Setelah membaca soal nomor 6 ini, apa yang pertama kali adek lakukan untuk menyelesaikan soalnya?

S2a-W605 Pertama itu kak, saya hitung jumlah kubusnya. Yang ini kak (menunjuk soal), kan k1 itu ada 4 kubus kak, terus $k 2$ itu ada 9 kubus, dan k3 itu ada 16 kubus kak Lalu kak saya lihat selisih antara k1 dan k2 kak. Ternyata selisihnya 5. Lalu selisihnya $k 3$ dengan $k 2$ lagi kak, selisihnya itu 7. Dari situ kak saya simpulkan kalau selisihnya itu kak bilangan ganjil. Nah bilangan ganjil setelah 7 itu kan 9 kak. Makanya saya jumlah kan total kubusnya $k 3$ dengan 9, nah saya peroleh jawabannya itu 25 kak. Jadi di k4 itu kak nanti ada 25 kubus yang bersusun. Jadi untuk k10 kak menurut perkiraan saya itu bilangan ganjil seterusnya ditambahkan. Maksudnya kak, kan saya dapatmi k4 itu 25 terus bilangan ganjil setelah 9 itu 11 jadi jumlahkan 25 dengan 11 hasilnya 36 kak berarti k5 nanti ada 36 susunan kubus. Nah 36 ini kak ditambah lagi dengan 13, begitu seterusnya kak sampai didapat k10. Seperti yang kayak saya tuliskan di jawaban saya kak. Nanti itu kak setelah dijumlahkan semua diperoleh k10 ada 121 kubus yang tersusun. 
Pada Transkrip 8, subjek S2a menjelaskan bagaimana ia menemukan pola untuk menyelesaikan permasalahan. Selain itu, subjek S2a juga menjelaskan langkah-langkah yang ia lakukan setelah menemukan pola tersebut sehingga memperoleh jawaban yang tepat. Oleh karena itu, subjek S2a telah menemukan pola dalam menyelesaikan permasalahan yang diberikan. Sehingga, dari hasil tes pada Gambar 8 dan hasil wawancara pada Transkrip 8, subjek S2a dapat memenuhi indikator menemukan pola dalam menyelesaikan permasalahan yang diberikan dengan tepat yang mewakili karakteristik pencarian pola.

\section{Subjek Berkemampuan Awal Geometri Rendah (S3a)}

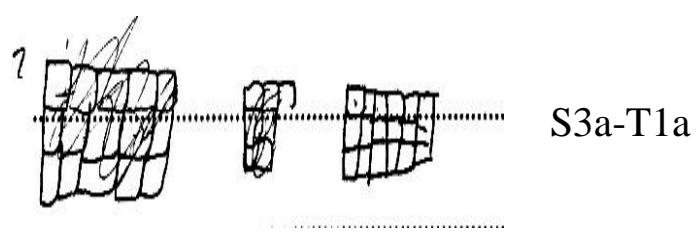

GAMBAR 9. Jawaban subjek S3a soal nomor 1

Pada Gambar 9, menuangkan idenya berupa gambar untuk menyelesaikan permasalahan di mana ia menggambarkan 3 buah bangun tetapi 2 di antaranya tampak dicoret (S3a-T1a). Bangun yang subjek S3a gambarkan lebih tampak seperti bangun persegi panjang dibandingkan balok seperti yang diinstruksikan oleh soal nomor 1. Oleh karena itu, meskipun subjek S3a telah menuangkan idenya dalam bentuk gambar namun belum menyelesaikan permasalahan yang diberikan. Hal ini diperkuat oleh cuplikan wawancara subjek S3a pada Transkrip 9.

\section{TRANSKRIP 9}

P2-07 Kenapa adek menggambarnya seperti ini?

S3a-W207 Awalnya kak saya berpikir bagaimana cara menggambarnya dan

berapa ukuran baloknya. Saya juga berpikir caranya agar

seimbang gambarnya. Akhirnya saya menggambarkan ini 3 ke atas

dan 6 samping. Jadi saya peroleh seperti itu.

P2-08 Kalau begitu, berapa panjang lebar dan tinggi dari balok yang adek gambarkan ini?

S3a-W208 Panjangnya 6 kak, lebarnya itu 3

S3a-W209 Tidak ada tingginya kak

S3a-W210 Karena dari yang saya gambar ini kak tidak ada tingginya cuman panjang dan lebarnya

Pada Transkrip 9, subjek S3a menjelaskan bangun yang ia gambarkan dan ukuran dari bangun tersebut, di mana berdasarkan penyataan subjek dapat disimpulkan bahwa subjek S3a memang hanya menggambarkan sebuah bangun persegi panjang bukan sebuah balok seperti yang diinstruksikan oleh soal (S3a-W210). Sehingga, dari hasil tes pada Gambar 9 dan hasil wawancara pada Transkrip 9, subjek S3a tidak dapat memenuhi indikator menuangkan ide atau hasil pemikirannya dalam bentuk gambar untuk menyelesaikan permasalahan yang diberikan dengan tepat yang mewakili karakteristik pengimajinasian.

Pada Gambar 10, subjek S3a menuliskan informasi yang ia peroleh dari soal (S3a-T2a). Kemudian, subjek menggunakan informasi tersebut untuk menyelesaikan operasi perhitungan yang ia tuliskan (S3a-T2b). Setelah memperoleh hasil, subjek S3a menyimpulkan jawaban yang ia dapatkan (S3a-T2c). Namun, jawaban yang dituliskan oleh subjek S3a ini tidak tepat dikarenakan ia tidak menggunakan rumus yang tepat dan tampak tidak memahami maksud soal dengan baik. Hal ini diperkuat dengan cuplikan wawancara subjek S3a pada Transkrip 10. 


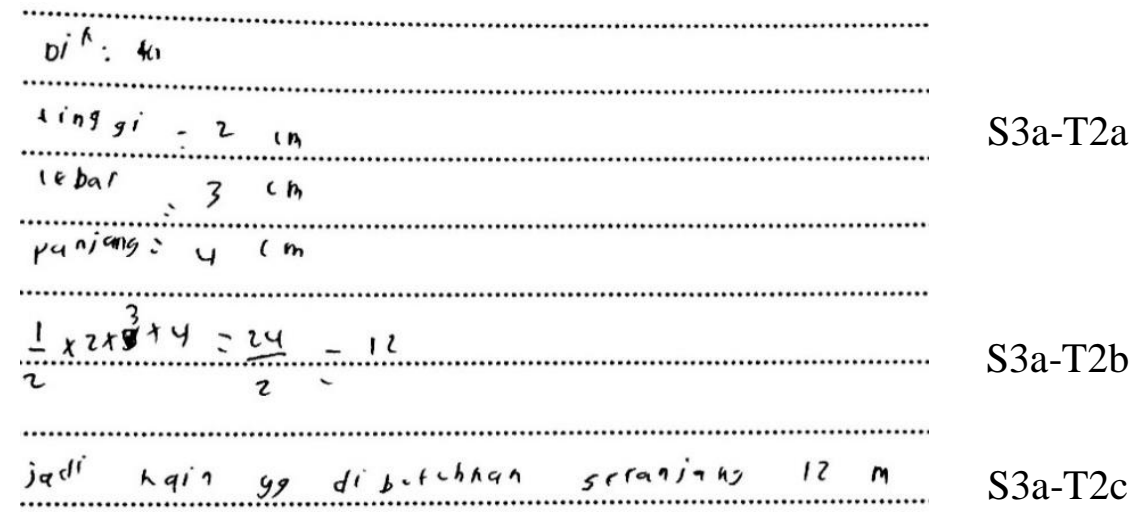

GAMBAR 10. Jawaban subjek S3a soal nomor 2

\section{TRANSKRIP 10}

P4-06 Oiye dek. Lalu apa yang pertama kali adek lakukan untuk menyelesaikan soalnya?

S3a-W406 Saya tinggal kalikan $1 / 2 x$ tinggi $x$ lebar $x$ panjang kak

P4-07 Kenapa seperti itu dek?

S3a-W407 Supaya mencakup semua luas yang dimaksud kak. Karena kalau

P4-08 Rumit bagaimana dek?

S3a-W408 Rumit langkahnya kak, saya juga tidak tahu caranya

Pada Transkrip 10, subjek S3a menjelaskan langkah yang ia gunakan untuk menyelesaikan permasalahan yang diberikan serta alasan mengapa ia memilih langkah tersebut (S3a-W407). Subjek S3a juga menyinggung mengenai sisi miring yang perlu dicari untuk menyelesaikan soal nomor 3 ini, yang artinya subjek S3a memahami maksud soal dengan baik. Namun, subjek S3a mengaku tidak mengetahui cara untuk mendapatkan sisi miring tersebut dan terkesan mudah menyerah (S3a-W408).

Subjek S3a tidak dapat menggunakan konsep yang ia ketahui untuk menyelesaikan permasalahan yang diberikan. Sehingga, dari hasil tes pada Gambar 10 dan hasil wawancara pada Transkrip 10, subjek S3a tidak dapat memenuhi indikator menggunakan konsep-konsep yang ia ketahui untuk menyelesaikan permasalahan yang diberikan yang mewakili karakteristik pengkonsepan.

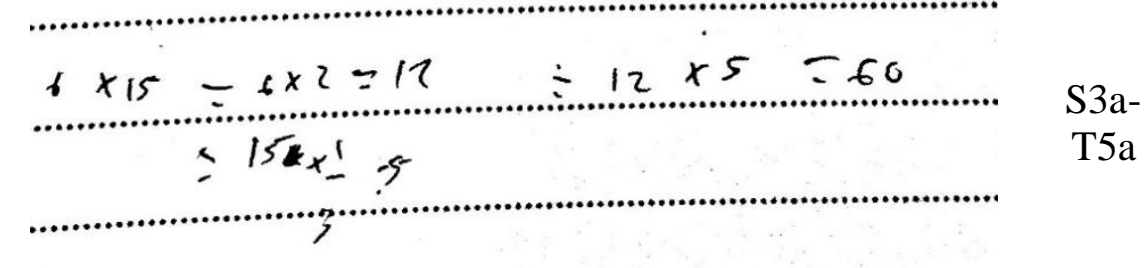

GAMBAR 11. Jawaban subjek S3a soal nomor 3

Pada Gambar 11, subjek S3a tidak menuliskan informasi yang ia ketahui dari soal namun langsung menuliskan beberapa operasi sehingga sulit memahami apa yang dituliskan subjek (S3a-T5a). Jawaban akhir yang dituliskan subjek pun tidak tepat sehingga subjek S3a tidak menyelesaikan permasalahan yang diberikan dengan benar. Hal ini diperkuat dengan cuplikan wawancara pada Transkrip 11. 


\section{TRANSKRIP 11}
P5-06
Jadi bagaimana cara adek menjawab soalmya?
S3a-W506 Kan panjang alasnya kak diperbesar 2 kali, panjang alas awalnya
kan kak 6 lalu saya ubah menjadi 12. Lalu 15 saya kalikan dengan
1/3 karena diperkecil kak terus saya peroleh 5 kak. Setelah itu saya
P5-08 kalikan 12 dengan 5 kak, makanya saya peroleh $60 \mathrm{kak}$.
S3a-W508 Tidak kak
P5-09
Jadi adek yakin sama jawabannya?
S3a-W509 Tidak kak, karena saya langsung kalikan saja

Pada Transkrip 11, subjek S3a menjelaskan operasi yang ia gunakan dalam menjawab soal nomor 3 (S3a-W506). Subjek S3a juga mengaku bahwa ia tidak mengetahui rumus dari volume lima situ sendiri dan tidak yakin dengan jawaban yang ia tuliskan tersebut (S3a-W508 \& S3aW509). Oleh karena itu, subjek S3a tidak menjawab soal yang diberikan dengan tepat. Sehingga, dari hasil tes pada Gambar 11 dan hasil wawancara pada Transkrip 11, subjek S3a tidak dapat memenuhi indikator menyelesaikan permasalahan yang diberikan dengan benar yang mewakili karakteristik pemecahan masalah.

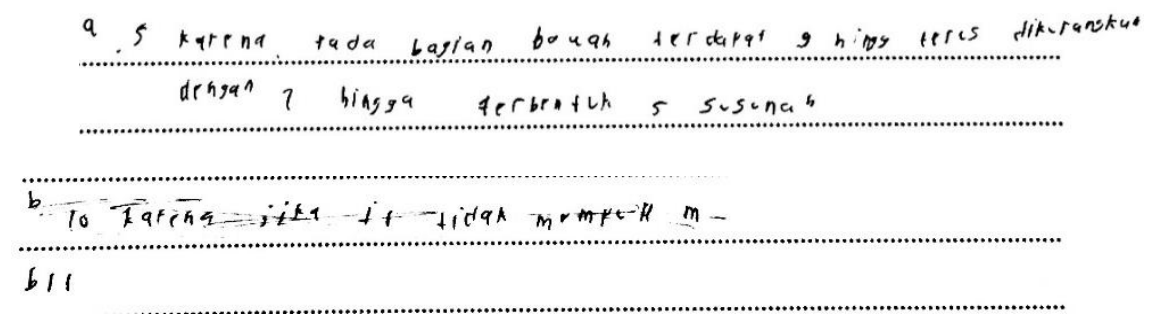

S3a-T4a

S3a-T4b

GAMBAR 12. Jawaban subjek S3a soal nomor 4

Pada Gambar 12, subjek S3a tampak tidak menuliskan pola yang ia temukan untuk menyelesaikan permasalahan yang diberikan dimana subjek hanya menuliskan jawaban dari $\mathrm{k} 4$ untuk bagian a serta alasan mengapa ia menuliskan jawaban tersebut (S3a-T4a). Begitu pula pada bagian b, subjek S3a hanya menuliskan jawaban untuk k10 yakni 11 tanpa alasan (S3aT4b). Hal ini diperkuat dengan cuplikan wawancara yang dapat dilihat pada Transkrip 12.

\section{TRANSKRIP 12}

P6-03 Jadi berapa jumlah kubus yang tersusun di k4 dek?

S3a-W604 5 kak

P6-05 Adek paham dengan soalnya tidak?

S3a-W606 (membaca soal lagi) Maksudnya kak ini mau dicari jumlah kubus yang tersusun pade kak? Saya kira jumlah susunan ke atasnya kak

P6-08 Jadi berapa jumlah susunan kubusnya dek?

S3a-W609 *menghitung* Ada 25 kak

P6-10 Jadi klo bagaimana dek? berapa jumlah susunan kubusnya dek?

S3a-W611 Banyak kak, tidak bisa saya hitung

Pada Transkrip 12, subjek S3a tampak tidak memahami maksud soal dengan baik, di mana bukannya menghitung jumlah kubus yang tersusun sesuai dengan yang diinstruksikan soal tetapi subjek S3a menghitung jumlah susunan kubus pada k4 dan k10 (S3a-W606). Selain itu, ketika subjek S3a ditanya mengenai jumlah kubus yang tersusun, ia tidak dapat menjawabnya (S3aW611).

Subjek S3a tidak dapat menemukan pola dalam menyelesaikan permasalahan dan juga salah memahami maksud soal. Sehingga, dari hasil tes pada Gambar 12 dan hasil wawancara pada Transkrip 12, subjek S3a tidak dapat memenuhi indikator menemukan pola dalam 
menyelesaikan permasalahan yang diberikan dengan benar yang mewakili karakteristik pencarian pola.

\section{KESIMPULAN}

Subjek berkemampuan awal geometri tinggi mampu memenuhi 3 karakteristik kecerdasan visual spasial yakni pengimajinasian, pengkonsepan serta pencarian pola. Sedangkan subjek berkemampuan awal geometri sedang mampu memenuhi 2 karakteristik kecerdasan visual spasial yakni pengimajinasian serta pencarian pola. Sementara, subjek berkemampuan awal geometri rendah tidak mampu memenuhi semua karakteristik kecerdasan visual spasial. Karakteristik pencarian pola dan pengimajinasian adalah karakteristik yang paling dominan (yang paling dipenuhi) di antara karakteristik yang lainnya, dan karakteristik pemecahan masalah adalah karakteristik yang paling sulit untuk dipenuhi oleh semua subjek.

Telah dipaparkan sebelumnya mengenai kecerdasan visual spasial dalam memecahkan masalah bangun ruang sisi datar ditinjau berdasarkan tingkat kemampuan awal geometri. Salah satu kekurangan dalam penelitian ini yaitu tidak memperhatikan perbedaan gender. Sehingga dalam penelitian ini tidak menunjukkan perbedaan spesifik mengenai kecerdasan visual spasial antara siswa laki-laki dengan siswa perempuan. Oleh karena itu, bagi penelitian lanjutan yang relevan, agar melakukan penelitian mengenai kecerdasan visual spasial berdasarkan kemampuan awal geometri yang juga memperhatikan gender siswa.

\section{DAFTAR PUSTAKA}

Achdiyat, M. \& Utomo, R. (2017). Kecerdasan Visual Spasial, Kemampuan Numerik, dan Prestasi Belajar Matematika. Jurnal Formatif, 3(7). 1-10.

Armstrong, T. (2013). Kecerdasan Multipel di dalam Kelas. Jakarta : Indeks.

Carter, P. (2010). Tes IQ dan Bakat : Menilai Kemampuan Penalaran Verbal, Numerik, dan Spasial Anda. Jakarta : Indeks.

Fadilah, E. N., \& Afifah, D.S.N. (2014). Kecerdasan Visual-Spasial Siswa SMP Dalam Memahami Bangun Ruang Ditinjau Dari Perbedaan Kemampuan Matematika. Jurnal Pendidikan Matematika, 2(2). 151-158.

Farisdianto, D. D., \& Budiarto, M. T. (2014). Profil Kemampuan Spasial Siswa SMP Dalam Menyelesaikan Masalah Geometri Ditinjau Dari Perbedaan Kemampuan Matematika. Jurnal Ilmiah Pendidikan Matematika, 3(2). 77-84.

Febriana, E. (2015). Profil Kemampuan Spasial Siswa Menengah Pertama (SMP) Dalam Menyelesaikan Masalah Geometri Dimensi Tiga Ditinjau Dari Kemampuan Matematika. Jurnal Elemen, 1(1). 13-23.

Gardner, H. (1983). Frames of Mind : The Theory of Multiple Intelligences. New York : Basic Books.

Librianti, D. L., Sunardi, Sugiarti. (2015). Kecerdasan Visual Spasial dan Logis Matematis dalam Menyelesaikan Masalah Geometri Siswa Kelas VIII A SMP Negeri 10 Jember. Artikel Ilmiah Mahasiswa, 1(1). 1-7.

Margaretha, P. M., Susanto, S.,Fatahillah, A. (2015). Kecerdasan Visual-Spasial Siswa SMP Berdasarkan Teori Hass Ditinjau dari Tingkat Kemampuan Geometri kelas IX-A SMP Negeri 1 Jember. Jurnal Edukasi, 2(3). 12-16.

Mas'um, A. (2013). Profil Kemampuan Penalaran Matematis Siswa dalam Menyelesaikan Soal Bangun Ruang Sisi Lengkung. Artikel Skripsi Gasal, 1(3). 
National Academy of Science. (2006). Learning to Think Spatially. Washington DC : The National Academics Press.

Ningsih, S. \& Budiarto, M. T. (2014). Kecerdasan Visual Spasial Siswa SMP dalam Mengkonstruksi Rumus Pythagoras dalam Pembelajaran Berbasis Origami di kelas VII. Jurnal Ilmiah Pendidikan Matematika, 3(1). 3-4.

Ningrum, D. I., \& Hermanto, D. (2018). Profil Kemampuan Spasial Siswa SMP dalam Menyelesaikan Masalah Geometri Ditinjau dari Perbedaan Gaya Kognitif. Jurnal Program Studi Pendidikan Matematika, 4(1). 16-23.

Pitriani. (2014). Pembelajaran Berbasis Masalah Berbantuan Program Komputer Cabri $3 d$ Untuk Meningkatkan Kemampuan Visual-Spatial Thinking Dan Habit Of Thinking Flexibly Siswa SMA (Tesis). Universitas Pendidikan Indonesia, Bandung.

Sari, M., Rizal, Muh., \& Hadjar, I. (2017). Profil Pemecahan Masalah Lingkaran Ditinjau Dari Tingkat Kecerdasan Visual-Spasial Siswa Kelas IX SMP. Jurnal Elektrik Pendidikan Matematika Tadulako, 4(4). 460-472. 